\title{
Drought vulnerability of Marathwada region, India: A spatial analysis
}

\author{
Sagar Khetwani ${ }^{1 \otimes}-$ Ram Babu Singh ${ }^{1}$ \\ ${ }^{1}$ Department of Geography, Delhi School of Economics, University of Delhi, Delhi 110007, Delhi, India \\ $\bowtie$ sagardse96@gmail.com
}

\begin{abstract}
The magnitude and frequency of severe and extreme drought events continue to grow, instigating a grave risk to human wellbeing. Marathwada region of India is one of the most chronically drought affected region of India. The sequential drought events between the years 2012 to 2016 acutely impacted the natural as well as socio-economic resources of the region. This study attempts to assess the drought vulnerability of Marathwada region at sub-district level. An integrated drought vulnerability index has been developed by blending biophysical and socio-economic indicators of drought vulnerability. The analysis revealed that sub-districts like Shirur-Anantpal, Deoni, Shirur Kasar, Dharur, Biloli, Paranda, Mukhed, Khuldabad, Patoda, Hadgaon, Palam, Badnapur and Kaij, emerged as the very highly vulnerable to drought, representing $14.43 \%$ of geographical area and $10.96 \%$ of population of Marathwada while the sub-districts lying under the category of high drought vulnerability represented $39.15 \%$ of geographical area and $34.69 \%$ of population.
\end{abstract}

\section{Keywords}

Drought vulnerability, Agriculture,

Exposure,

Sensitivity,

Adaptive capacity,

Marathwada region

Received:

27 July 2020

Received in revised form:

14 November 2020

Accepted:

16 November 2020

\section{Highlights for public administration, management and planning:}

- The impacts of droughts are more acute in developing countries which are highly dependent on agriculture.

- Spatial assessment of drought vulnerability is one of the most significant tasks of public administration in the arid and semi-arid regions for developing the appropriate region-specific drought management strategies.

- An integrated drought vulnerability index has been prepared by taking into consideration both biophysical and socio-economic indicators for the comprehensive assessment of drought vulnerability.

\section{Introduction}

The increased drought events threaten humankind, and evidence indicates that throughout the world, the frequency and intensity of drought events are increasing. There is not any globally accepted operational definition for drought that fits to all contexts because of complex features of drought and its effects across diverse geographical regions, such as rainfall intensity and patterns, anthropogenic response and resilience (Polsky \& Cas 2005; Basu et al. 2017; Hayes et al. 2005; Squires 2017; Wilhite et al. 2005). Drought is generally characterized as prolonged phase marked by prolonged dry spells and a severe water supply deficiency (Centre for Research on the Epidemiol- ogy of Disasters (CRED) 2015; Action Aid 2016). The increased frequency, extensive spatial extent, and a long temporal duration make drought more complex among all natural hazards (Murthy et al. 2015a; Dalezios et al. 2017; Kayam \& Beyazgul 2017). In developing economies, drought would trigger massive socio-economic losses and further threatens the ecological and human health and wellbeing (Dandekar \& Thakkar 2013; Deulgaonkar 2015; Kale \& Gond 2016).

The long-term adverse impacts prevail even after the drought end (Hohenthal \& Minoia 2017; Haque et al. 2017; Fakhruddin \& Eslamian 2017). The intensification of drought events in India and many developing nations across the world has increased the significance of Disaster Risk Reduction (DRR) to increase drought resilience 
(Action Aid 2016). The existing drought assessment systems comprise of several drought indices that widely focuses on short-term drought management strategies (Vedeld et al. 2014; Wilhite et al. 2005). Drought vulnerability assessment can also play a decisive role in reducing biophysical and socio-economic losses due to impacts of drought (Murthy et al. 2015b; Kar et al. 2018; Thomas et al. 2016). The Sendai Framework for Disaster Risk Reduction stresses on the need for micro level drought vulnerability assessment.

Kar et al. (2018) assessed the drought vulnerability for Dhasan region in Madhya Pradesh state of India. They have adopted an integrated drought vulnerability approach by integrating vulnerability factors in order to get better result for drought assessment. Karamouz et al. (2015) analyzed the spatial characteristics of drought vulnerability of East Azarbaijan province of Iran. They had done the time series analysis of factors like temperature, precipitation, solar radiation, land use and ground water elevation, and a multi-criteria decision making approach had been adopted to assess the consistency of the provided information. Murthy et al. (2015a) developed an integrated index for drought vulnerability assessment of 1038 Mandals (administrative units). Their study area was former Andhra Pradesh, India. They analyzed the statistical records on agricultural land holdings, rainy days, rainfall, irrigation, soils, agricultural pattern and remote sensing based crop health. They incorporated 22 input indicators of drought vulnerability which were separated into different components.

The available literature of vulnerability are studied more at a national or regional level (macro level), whereas a micro level drought vulnerability assessment could prove an effective drought risk reduction measure (Murthy et al. 2015a; Rama Rao et al. 2016; Ravindranath et al. 2011). There is scarce availability of literature related to drought vulnerability at micro level. Though, Swami et al. (2018) attempted to address the agricultural susceptibility of Maharashtra state to monsoon variability at district level. In their study they ranked the districts of state with the help of monsoon variability index that includes six varied monsoon variability parameters, i.e., wet/dry spells, frequency/intensity of extreme rainfall events, deviation from the long-period average and daily-scale variability by applying factor analysis. Their study highlights that districts of regions like Marathwada and Vidarbha are at highest risk that requires significant attention from researchers and policy-makers. By taking into consideration the limitations of previ- ous studies, current study not just relies on physical factors but also incorporates the socio-economic factors like irrigation support, land holdings, level of literacy and medical facilities.

The specific objectives of this study are to assess the spatial distribution of drought vulnerability at sub-district level and to identify the critical subdistricts from the point of view of drought vulnerability. The spatial computation and usage of composite indices from physical and socio-economic data has been extensively employed and these methods have been used in this research work to assess drought vulnerability. An integrated drought index has been prepared in this study by integrating the biophysical and socio-economic indicators of drought after reviewing the above literature related to drought vulnerability.

\section{Study area}

The study concentrates around Marathwada region, located in Maharashtra state of India. The region has a total geographical area of 64,813 sq. $\mathrm{km}$ (Planning Department Government of Maharashtra (PDGOM) 2013). The latitudinal extent of Marathwada is $17^{\circ} 37^{\prime}$ North and $20^{\circ} 39^{\prime}$ North while longitudinal extent is $74^{\circ} 33^{\prime}$ East and $78^{\circ} 22^{\prime}$ East longitudes (Groundwater Surveys and Development Agency (GSDA) 2017; Maharashtra Status of Environment and Related Issues (ENVIS$\mathrm{MAH}$ ) 2007). The Marathwada comprises of eight districts and seventy-six sub-districts in eight districts (Fig. 1). The region is located in the rainshadow belt of Sahyadri mountain range at Western Ghats of Maharashtra (PDGOM 2013; ENVISMAH 2007). The average temperature of day varies between 27.7 to $38.0^{\circ} \mathrm{C}$ and the mean temperature of night ranges from 20.0 to $26.9^{\circ} \mathrm{C}$ (ENVIS-MAH 2007). The normal average rainfall is about $825 \mathrm{~mm}$ but is highly erratic and often there is a significant time gap between the two successive showers of rain (GSDA 2017). The Godavari is a most important river of the region, also known as 'Ganges of Deccan' and comprises many large and small scale irrigation projects (ENVIS-MAH 2007). As per the estimates of 2011 census report, the population of Marathwada region is 18731 872. A large section of Marathwada's population around $74 \%$ is reliant on agricultural sector (PDGOM 2013). 


\section{sciendo}
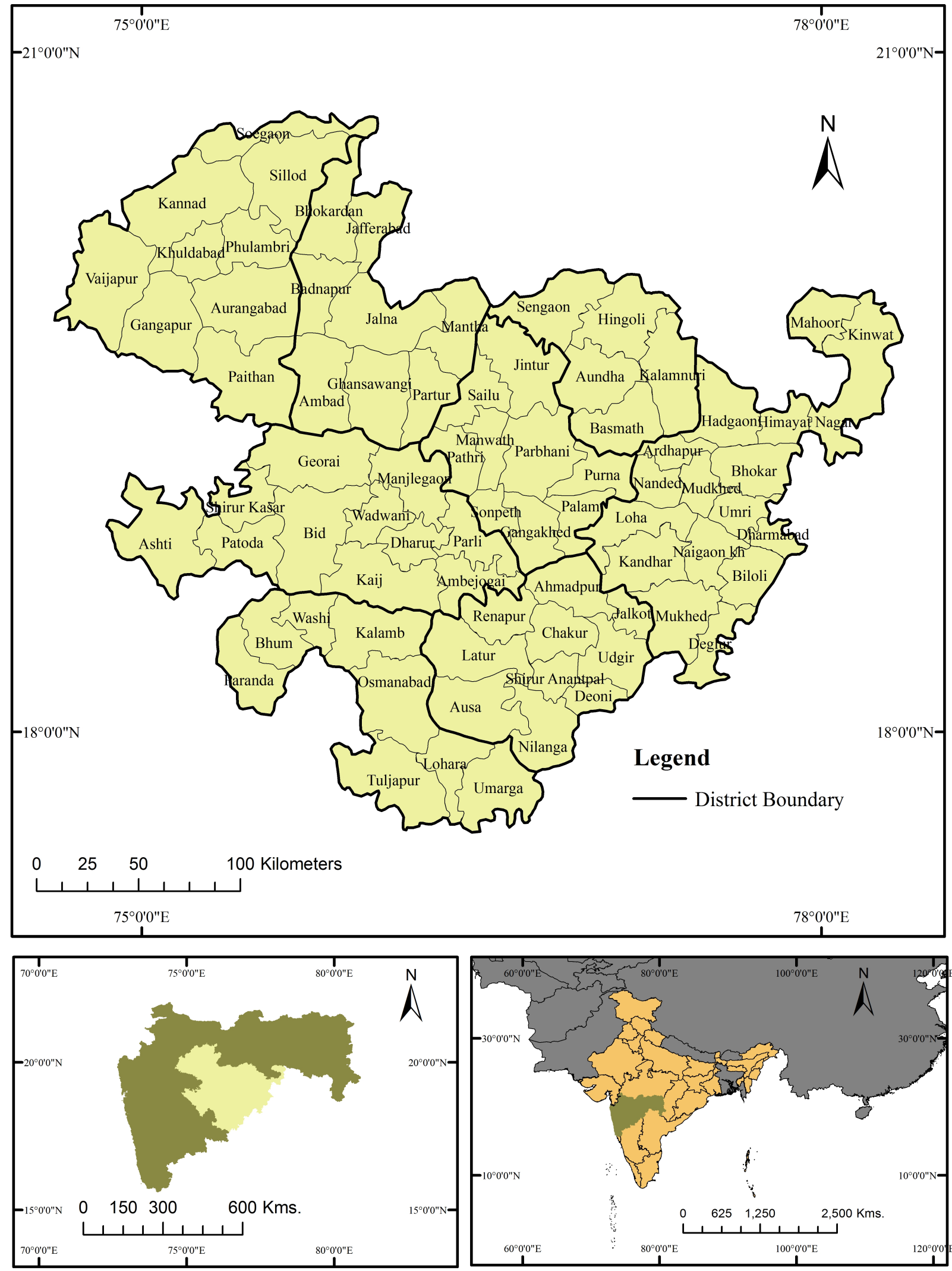

Fig. 1 Location Map of the Study Area, Marathwada Region. Source: Census of India (2011). 


\section{Materials and Methods}

\subsection{Drought vulnerability components}

This study uses the three main components of drought vulnerability, i.e. exposure, sensitivity and adaptive capacity. The integrated assessment of drought vulnerability has been done. Earlier studies on drought and climate change vulnerability like Murthy et al. (2015a), Murthy et al. (2015b), Rama Rao et al. (2016) have incorporated these three components effectively. The indicators of drought vulnerability, i.e. average and coefficient of variation of total monsoon rainfall, sowing period rainfall, total rainy days during monsoon season, total rainy days during sowing period and frequency of drought during sowing period and total monsoon rainfall have also been used by Murthy et al. (2015a) for the computation of exposure component of drought vulnerability. The drought vulnerability indicators for the assessment of sensitivity component have been selected after the study of the research work of Murthy et al. (2015b). Under the adaptive capacity component indicators like irrigation support, land holdings, level of literacy and medical facilities have been added by the authors for taking into account the socio- economic dimensions of drought vulnerability along with the physical components of drought vulnerability, i.e. exposure component and sensitivity component. Composite index has been calculated for each of the three components of drought vulnerability and further these are integrated in to a single vulnerability index (Fig. 2).

The selection of appropriate indicators has been done not only on the basis of availability of data but also to make an integrated assessment on the basis of previous studies conducted (Murthy et al. 2015a; Murthy et al. 2015b; Rama Rao et al. 2016; Ravindranath et al. 2011). This integrated assessment approach of drought vulnerability blends both biophysical and socio-economic approaches of drought vulnerability. The information related to the indicators of drought vulnerability and their relationship with the components and their weightage are provided (Table 1).

\subsection{Exposure constituents}

Exposure specifies the frequency and intensity of drought conditions over a sub-district. Meteorological drought usually triggers hydrological and agricultural drought. In this study rainy days and rainfall are taken as important determinants of the exposure component. The sec-

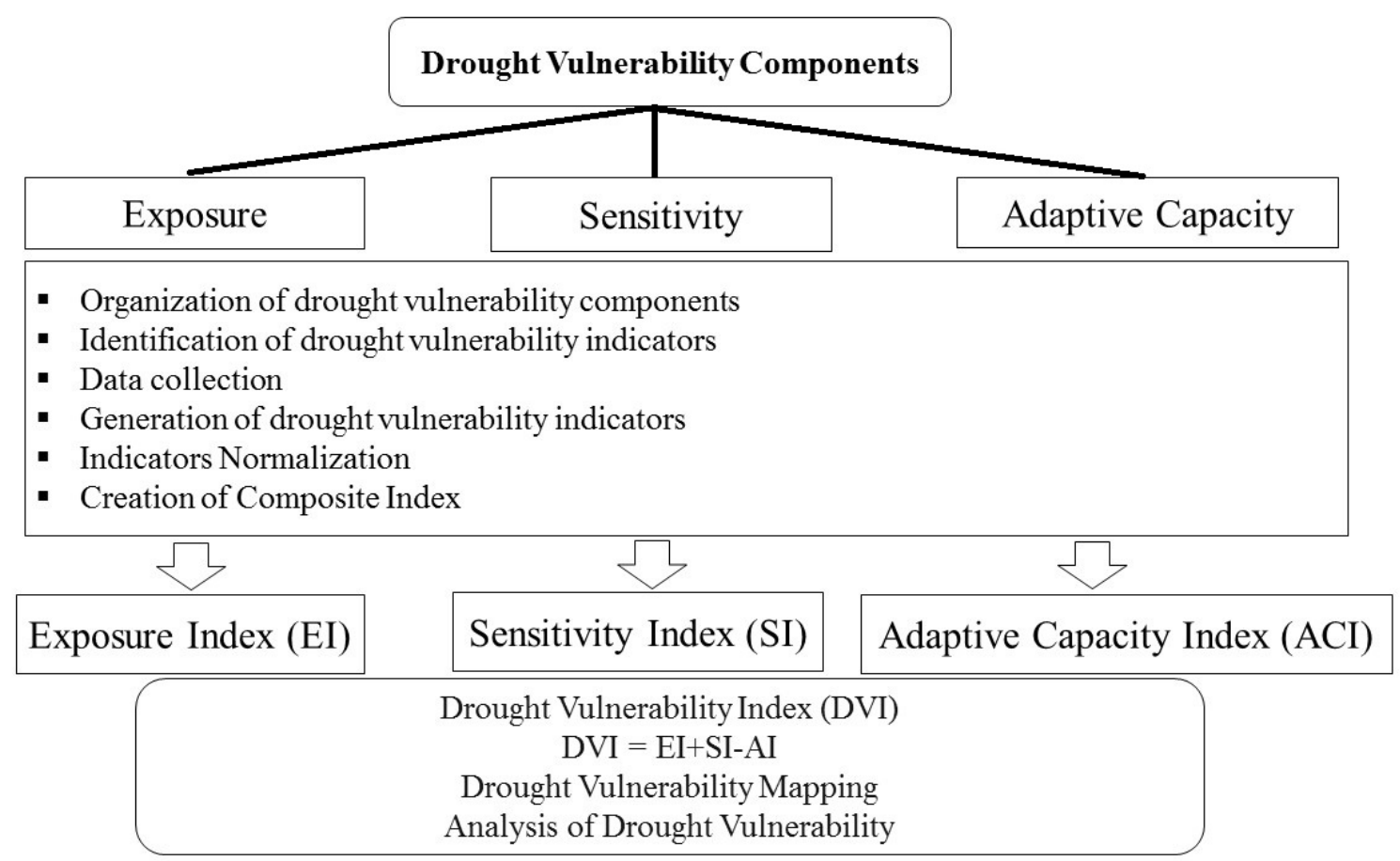

Fig. 2 Drought vulnerability components. 
Table 1 Drought vulnerability components, parameters and indicators.

\begin{tabular}{|c|c|c|c|}
\hline Parameter & Indicator & $\begin{array}{l}\text { Functional relationship } \\
\text { with component index }\end{array}$ & Weight \\
\hline \multicolumn{4}{|l|}{ A. Exposure } \\
\hline \multirow{3}{*}{$\begin{array}{l}\text { Total monsoon } \\
\text { rainfall (JJAS) }\end{array}$} & a) Average & Negative & 0.09 \\
\hline & b) Coefficient of Variation & Positive & 0.14 \\
\hline & c) Frequency of Drought & Positive & 0.08 \\
\hline \multirow{3}{*}{$\begin{array}{l}\text { Sowing } \\
\text { period rainfall }\end{array}$} & a) Average & Negative & 0.10 \\
\hline & b) Coefficient of Variation & Positive & 0.09 \\
\hline & c) Frequency of Drought & Positive & 0.09 \\
\hline \multirow{2}{*}{$\begin{array}{l}\text { Total rainy days } \\
\text { during monsoon season }\end{array}$} & a) Average & Negative & 0.07 \\
\hline & b) Coefficient of Variation & Positive & 0.19 \\
\hline \multirow{2}{*}{$\begin{array}{l}\text { Total rainy days } \\
\text { during sowing period }\end{array}$} & a) Average & Negative & 0.08 \\
\hline & b) Coefficient of Variation & Positive & 0.07 \\
\hline \multicolumn{4}{|l|}{ B. Sensitivity } \\
\hline \multirow{2}{*}{$\begin{array}{l}\text { Season's Integrated } \\
\text { NDVI }\end{array}$} & a) Coefficient of Variation & Positive & 0.21 \\
\hline & b) Frequency of Drought & Positive & 0.19 \\
\hline \multirow{2}{*}{ NDVI (August) } & a) Coefficient of Variation & Positive & 0.22 \\
\hline & b) Frequency of Drought & Positive & 0.19 \\
\hline $\begin{array}{l}\text { Season's Integrated } \\
\text { NDVI Range }\end{array}$ & Range & Positive & 0.19 \\
\hline \multicolumn{4}{|c|}{ C. Adaptive capacity component } \\
\hline Irrigation support & Percent of irrigated crop area & Positive & 0.33 \\
\hline Land holdings & Percent of area under landholdings less than 2 hectares & Negative & 0.37 \\
\hline Level of literacy & Literacy rate & Positive & 0.14 \\
\hline Medical facilities & Percent of rural population served by medical facilities & Positive & 0.16 \\
\hline
\end{tabular}

ondary data related to the rainy days and rainfall have been collected from the state agricultural department. The sub-district wise daily rainfall data for the months June to September for 12 years (2006-2017) has been examined for generating the indicators of exposure component. The rationale behind the selection of period of 12 years is to signify the recent status. In this study, a rainy day is considered as the day with equal to or more than $2.5 \mathrm{~mm}$ of rainfall while meteorological drought is considered when rainfall in any sub-district is less than $75 \%$ of normal rainfall, as considered by India Meteorological Department. In this study average of rainfall for 12 years (2006 to 2017) for the months June to September has been considered as normal rainfall. Early season drought at the time of sowing of crop is a significant factor of the Marathwada region due to failure of monsoon in the month of July.

\subsection{Sensitivity constituents}

The sensitivity constituent signifies the extent to which the agricultural crops of Marathwada region are affected. It is denoted through the satellitebased crop health status in the form of remotesensing derived Normalized Difference Vegetation Index (NDVI). It includes the Season's Integrated NDVI (SIN), NDVI (August) and Season's Integrated NDVI Range. In many of the studies NDVI has been widely utilized for drought assessment due to its easiness in computation and analysis. The present study uses the Terra MODIS $250 \mathrm{~m}$ NDVI data from the July to October months (2006-2017), provided by the National Agricultural Drought Assessment and Monitoring System (NADAMS) project. It is the project developed by National Remote Sensing Centre which provides near real-time information on prevalence and intensity level of agricultural drought at state/ district/sub-district level. The SIN has been computed by summation of four months 
NDVI (June, July, August and September) of every year, i.e., 2006 to 2017. SIN represents aggregate vegetation biomass and its health. While the August month NDVI appropriately represents the early season agricultural drought stress. Hence, NDVI data for the month of August between the years 2006 to 2017 has been used to derive coefficient of variation and drought frequency. The drought sensitivity indicators like coefficient of variation, drought frequency and range have been derived from SIN. SIN range denotes the variance between maximum and minimum values of SIN during the 2006 to 2017 and it depicts the magnitude of NDVI change while coefficient of variation specifies the mean inter-annual variability between the years 2006 to 2017. Both higher the coefficient of variation and range designates the more is the drought vulnerability. The Season's Integrated NDVI based drought frequency has been calculated through generating standardized SIN for each year with the help of Z-scores of SIN distribution as adopted by Peters et al. (2002). Standardised SIN of less than 0.25 for a given year between the years 2006 to 2017 is regarded as agricultural drought and further its frequency has been calculated.

\subsection{Adaptive capacity constituents}

It represents the capacity of dealing with the drought stress. The drought vulnerability indicators under adaptive capacity component include irrigation support, land holdings, level of literacy and medical facilities. The rationale behind selecting percent of irrigated crop area as a crucial indicator is that in semi-arid regions irrigation plays an important role in reducing the drought risk particularly during prolonged phase of dry spells. The percent of geographical land under landholdings occupied by marginal and small farmers has been taken as indicator because of the rationale that they have comparatively less adaptive capacity than large farmers. The level of literacy and medical facilities denotes the socio-economic wellbeing to mitigate drought stress.

\subsection{Drought vulnerability data analysis}

This study incorporated 10 drought vulnerability indicators under Exposure constituent, 5 indicators under Sensitivity constituent and 4 indicators under Adaptive capacity component for 76 sub-districts. The technique of data normalization, i.e., Min-max has been adopted in order to normalize the data and to maintain their functional relationships with drought vulnerability component index. $\mathrm{X}$ indicator over i number of sub-districts that is positively linked to corresponding constituent index has been normalized with the Equation 1.

$$
X_{\text {normalized }}=\frac{X_{i}-X_{\min }}{X_{\max }-X_{\min }}
$$

When $\mathrm{X}$ is negatively linked to the respective constituent index, then normalization has been done through Equation 2.

$$
X_{\text {normalized }}=\frac{X_{\max }-X_{i}}{X_{\max }-X_{\min }}
$$

$\mathrm{X}_{\max }$ denotes the maximum value of $\mathrm{X}$ indicator among all sub-districts while $\mathrm{X}_{\min }$ denotes the minimum value of $X$ indicator among all sub-districts.

The weights provided to the drought vulnerability indicators have been based on the basis of discussions with subject experts and of a literature review. Subject experts indulged in the field of agriculture, meteorology, groundwater management and watershed development in the Aurangabad division of Maharashtra state have been individually consulted. Assigning of weights to vulnerability indicators on the basis of subject experts have also been done in studies like Swain \& Swain (2011) and Ravindranath et al. (2011). The values of weights range between 0 to 1 . The sum of all the weights is equal to 1 . The drought vulnerability has been computed in Equation 3.

$$
\text { Drought Vulnerability }=E I+S I-A C I
$$

EI denotes Exposure Index, SI Sensitivity Index and ACI Adaptive Capacity Index. Further, it has been classified into four categories of drought vulnerability: Low (0 to 0.25$)$, Moderate (0.25 to 0.50$)$, High (0.50 to 0.75 ) and Very High (0.75 to 1 ). ArcGIS 10.2.2 mapping software has been used for showing the spatial distribution of drought vulnerability at sub-district level.

\section{Results}

Spatial maps of composite indices of exposure, sensitivity and adaptive capacity in the study area were prepared and analyzed. These composite indices namely exposure index (EI), sensitivity index (SI) and adaptive capacity index (ACI) represent the exposure, sensitivity and adaptive capacity of sub-districts to the drought. Categorization of sub-districts based on EI has been depicted in Fig. 3. The northwestern part of the region including Aurangabad district has less number 


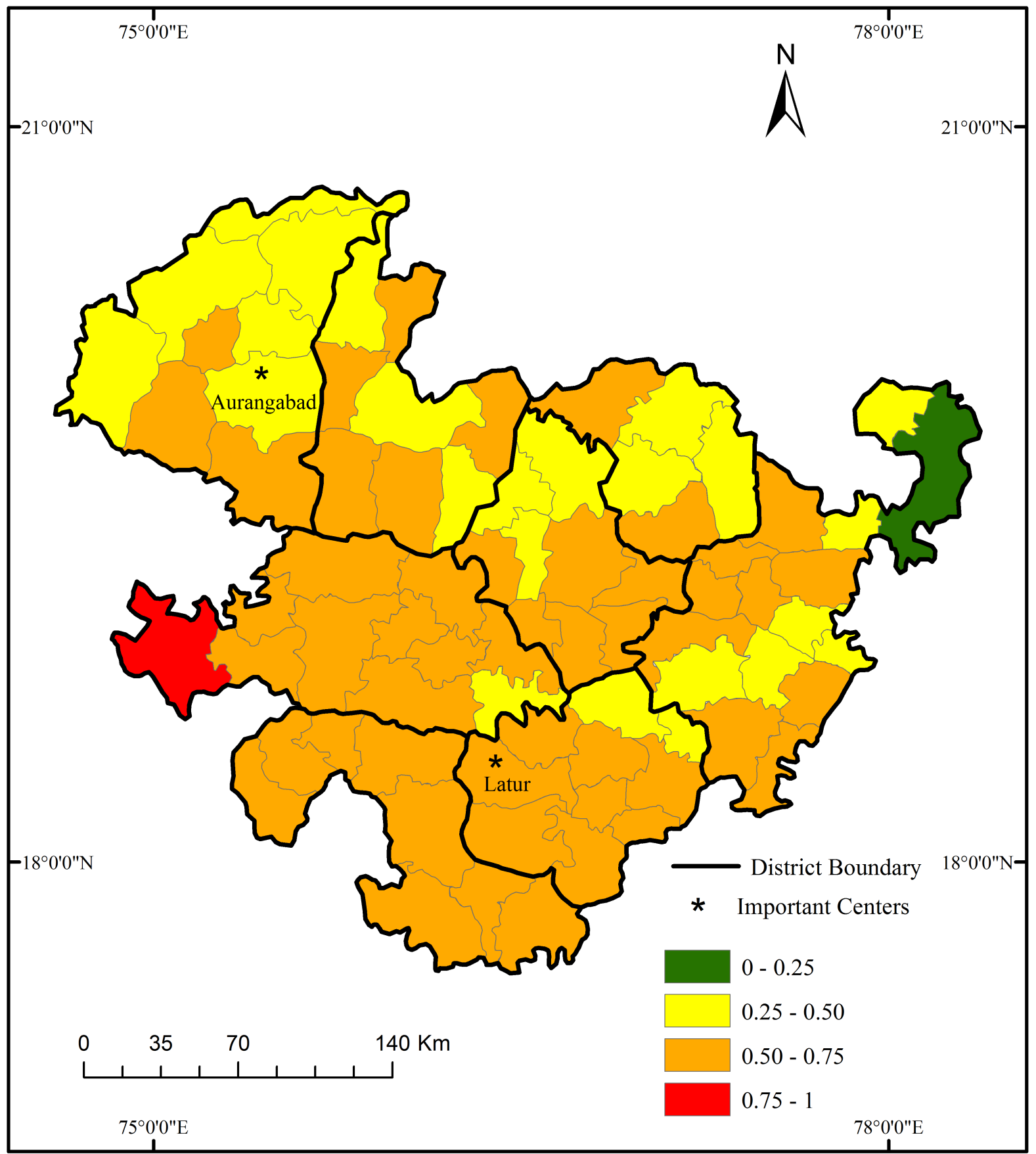

Fig. 3 Spatial distribution of exposure index.

of sub-districts with EI values $(\mathrm{EI}<0.5)$ as compared to the southern and southeastern part which have large share of sub-districts with (EI $>0.5)$. The subdistricts with high exposure to drought are dominated in districts, i.e. Osmanabad, Latur and Bid. These districts are quite infamous for characteristics like low seasonal rainfall and high rainfall variability. The northwestern region of the study area, experiencing comparatively higher rainfall, shows lesser EI values. Sub-districts with different category of EI could be seen as 24 sub-districts with moderate exposure to drought (EI 0.25-0.50) and 51 sub-districts with high and very high exposure to drought (EI >0.50). Nearly about $32 \%$ of sub-districts are moderately exposed and around $67 \%$ are comparatively more exposed to meteoro- 


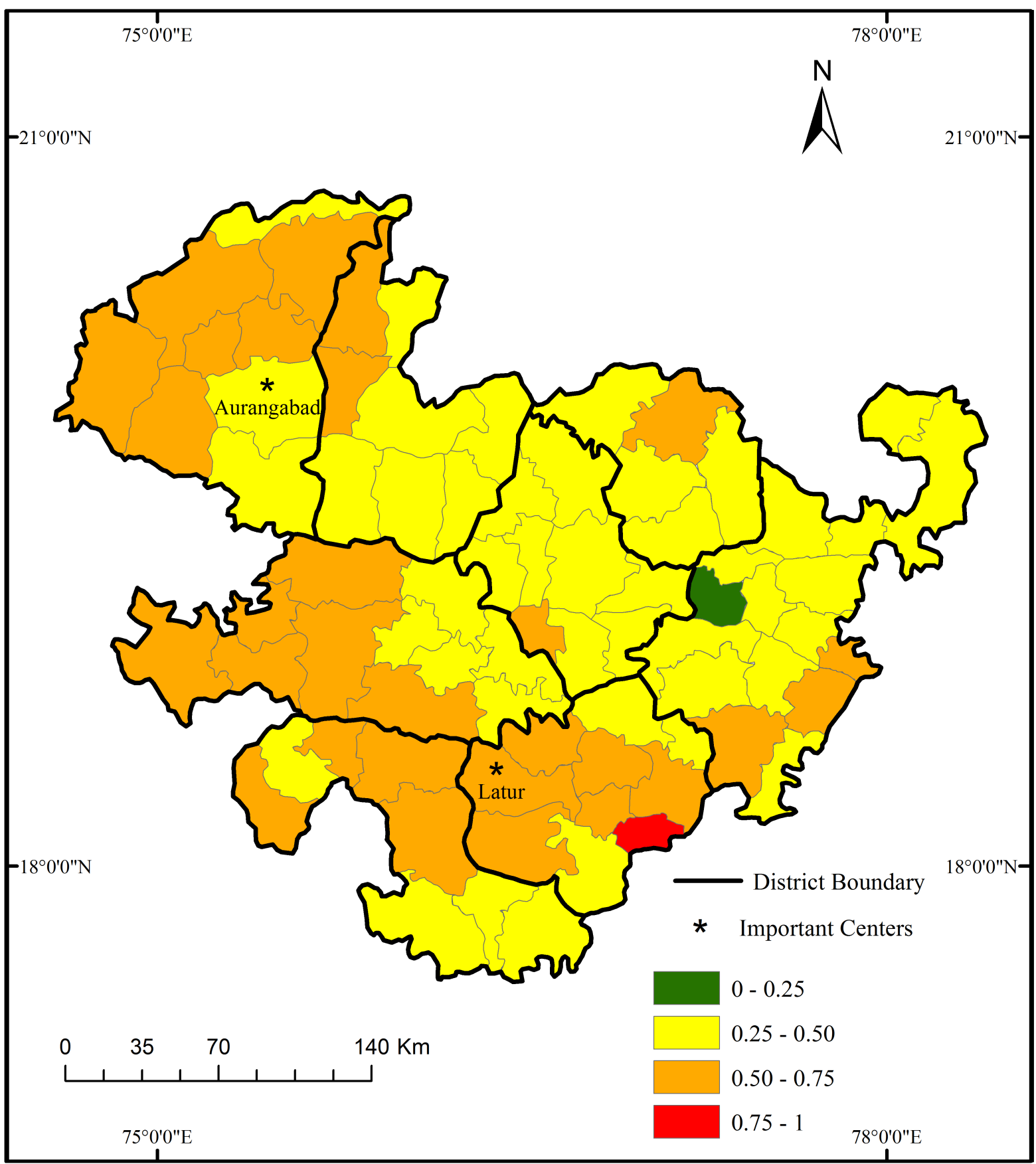

Fig. 4 Spatial distribution of sensitivity index

logical drought. Thus, the exposure level of study area showed spatial variability.

Spatial distribution of SI in the study area has been shown in Fig. 4. The sensitivity index is fundamentally based on the derivatives of vegetation health and its variability. It has been found that crop health and its variability in majority of sub-districts are moderately sensitive to agricultural drought. The moderate level of sensitivity (SI 0.25-0.50) is found in 45 sub-districts. High level of SI (0.50-0.75) has been found in 29 sub-districts while one is marked with very high SI $(>0.75)$. Around $40 \%$ sub-districts have shown high and very high sensitivity to drought, distributed in the Latur, Aurangabad, Bid and Osmanabad district.

Distribution of ACI in the region is shown in Fig. 5 . The results show that 42 sub-districts have moderate adaptive capacity to drought (ACI 0.25-0.50) 


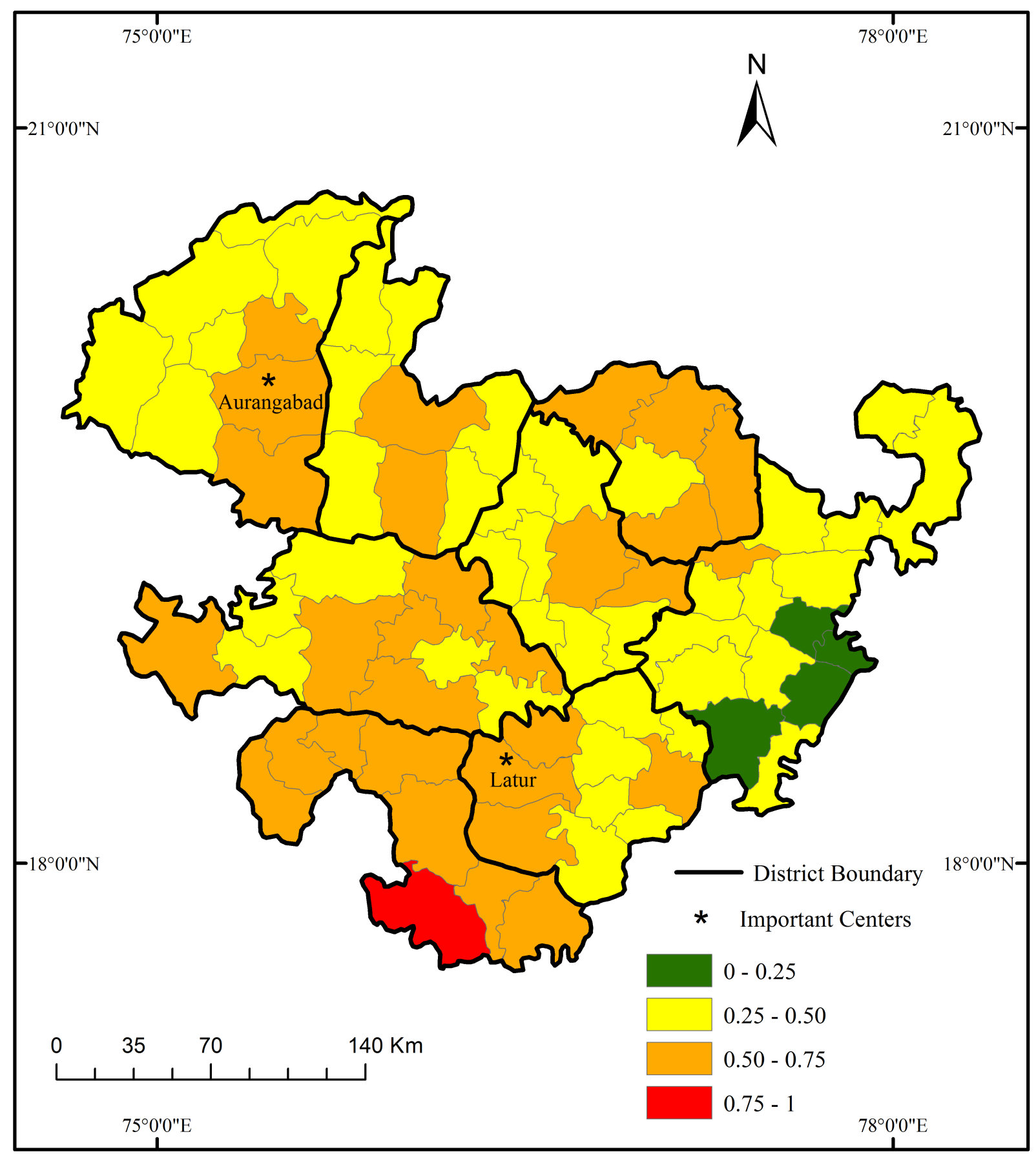

Fig. 5 Spatial distribution of adaptive capacity index

while 4 are marked with low adaptive capacity (ACI $<0.25), 29$ sub-districts have high adaptive capacity (ACI 0.50-0.75) and 1 have very high adaptive capacity (ACI >0.75). The overall analysis shows that around 55\% sub-districts are categorized under moderate ACI category. The Osmanabad and Hingoli are marked with the large share of sub-districts having high to very adaptive capacity to drought.
The overall drought vulnerability of the study area has been shown in Fig. 6 and Fig. 7. There are 4 sub-districts under the category of low vulnerability to drought, 32 sub-districts are under moderately vulnerable class, 27 sub-districts are highly vulnerable and 13 sub-districts are very highly vulnerable. The analysis revealed that sub-districts like ShirurAnantpal, Deoni, Shirur Kasar, Dharur, Biloli, 


\section{sciendo}

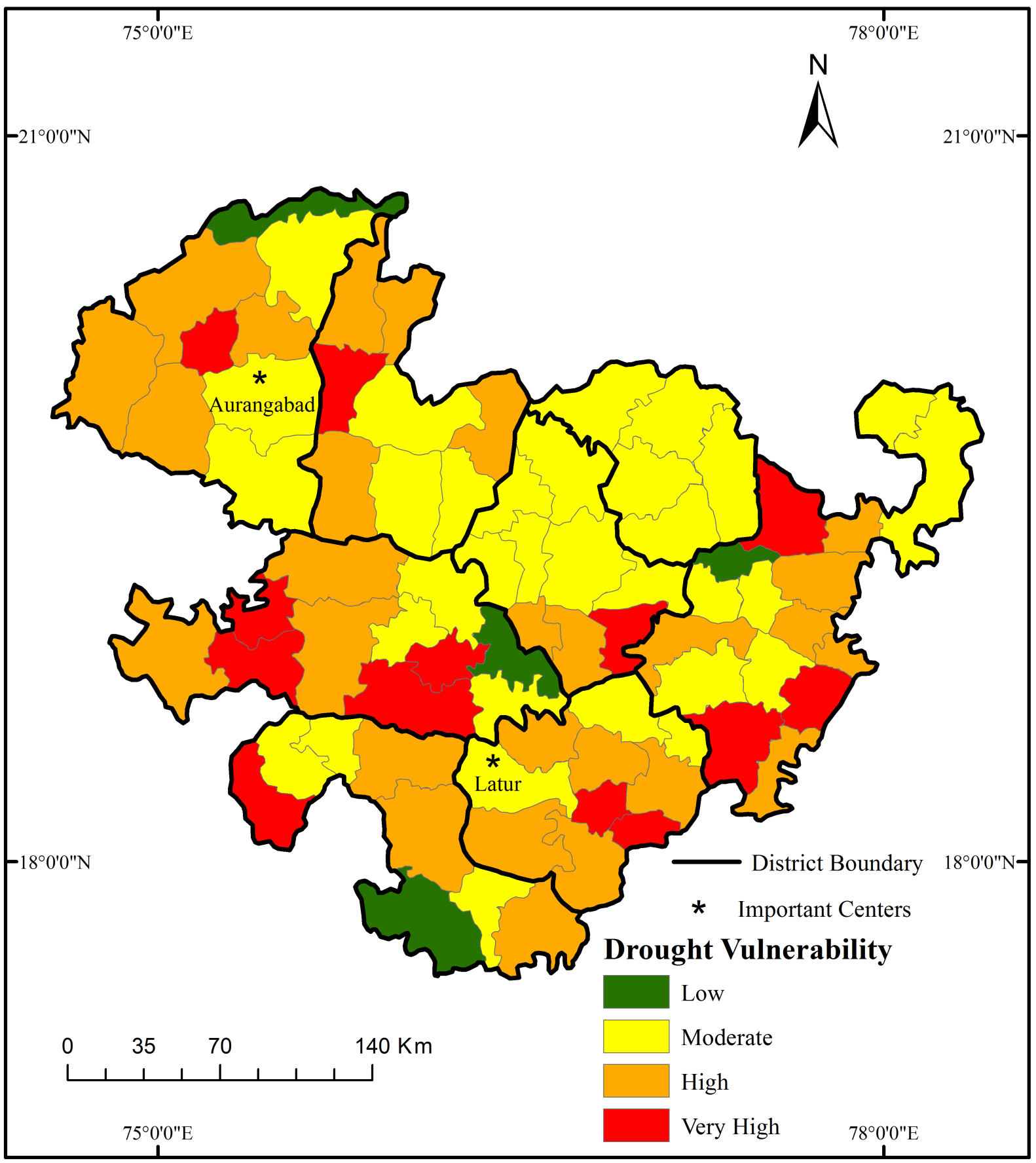

Fig. 6 Spatial distribution of drought vulnerability index

Paranda, Mukhed, Khuldabad, Patoda, Hadgaon, Palam, Badnapur and Kaij, emerged as the very highly vulnerable to drought, representing $14.43 \%$ of geographical area and $10.96 \%$ of population of Marathwada. The sub-districts lying under the class of high drought vulnerability represented $39.15 \%$ of geographical area and $34.69 \%$ of population. While the sub-districts lying under the mod- erate drought vulnerability category represented $41.51 \%$ of geographical area and $50.15 \%$ of population of the region. The sub-districts like Soegaon, Tuljapur, Ardhapur and Parli lies at the bottom of the category representing $4.90 \%$ of geographical area and $4.21 \%$ of population (Table 2 ). 


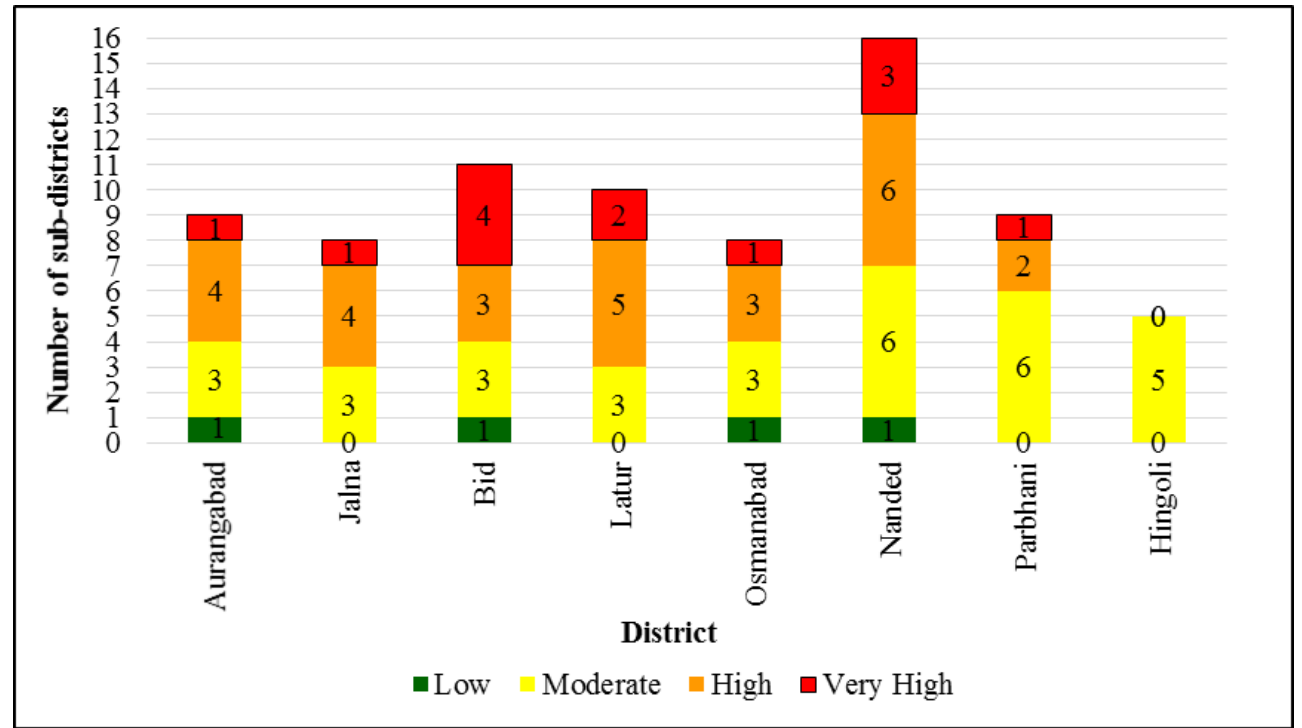

Fig. 7 District wise Distribution of Drought Vulnerable Sub-districts

Table 2 Analysis of drought vulnerability

\begin{tabular}{|c|c|c|c|}
\hline $\begin{array}{l}\text { Drought } \\
\text { Vulnerability }\end{array}$ & Sub-district/s & $\begin{array}{l}\text { Per cent of } \\
\text { Geographical Area }\end{array}$ & $\begin{array}{l}\text { Per cent of } \\
\text { Population }\end{array}$ \\
\hline Very high & $\begin{array}{l}\text { Shirur-Anantpal, Deoni, Shirur Kasar, } \\
\text { Dharur, Biloli, Paranda, Mukhed, Khuldabad, } \\
\text { Patoda, Hadgaon, Palam, Badnapur and Kaij }\end{array}$ & 14.43 & 10.96 \\
\hline High & $\begin{array}{l}\text { Georai, Kalamb, Sonpeth, Bhokar, Gangapur, } \\
\text { Dharmabad, Ashti, Gangakhed, Vaijapur, Deglur, } \\
\text { Himayat Nagar, Umri, Mantha, Nilanga, Ambad, } \\
\text { Osmanabad, Ausa, Chakur, Renapur, Jafferabad, } \\
\text { Udgir, Bhokardan, Bid, Phulambri, Kannad, } \\
\text { Loha and Umarga }\end{array}$ & 39.15 & 34.69 \\
\hline Moderate & $\begin{array}{l}\text { Sailu, Latur, Sillod, Mudkhed, Ahmadpur, } \\
\text { Pathri, Lohara, Ambejogai, Hingoli, Wadwani, } \\
\text { Naigaon (Khairgaon), Kalamnuri, Purna, Jalna, } \\
\text { Kandhar, Parbhani, Washi, Paithan, Mahoor, } \\
\text { Nanded, Ghansawangi, Partur, Aundha, Jintur, } \\
\text { Bhum, Manwath, Sengaon, Basmath, Manjlegaon, } \\
\text { Jalkot Kinwat and Aurangabad }\end{array}$ & 41.51 & 50.15 \\
\hline Low & Soegaon, Tuljapur, Ardhapur and Parli & 4.90 & 4.21 \\
\hline
\end{tabular}

\section{Discussion}

In the previous studies attention has been paid at district level while in this study micro level analysis has been made at sub-district level to make this study more precise in order to formulate the better policies for drought risk reduction. This study has identified sub-districts marked with very high and high drought vulnerability and also suggests for micro level sub-district specific remedial measures in order to increase the adaptive ca- pacity in the identified critical sub-districts for reducing the drought vulnerability.

The analysis of data revealed that sub-districts like Kalamb, Purna, Bhum, Kaij, Lohara, Paranda, Umarga, Shirur Kasar, Dharur and Ashti are found with comparatively higher exposure to drought because of low seasonal rainfall and high rainfall variability as compared to the other sub-districts. Among these above mentioned sub-districts it is also interesting to found that Kaij, Paranda, Shirur Kasar and Dharur lies under the class of very highly drought vulnerable after an overall drought vulnera- 
bility analysis while Kalamb, Umarga and Ashti have high drought vulnerability. It also shows the comparatively high sensitivity and accordingly poor adaptive capacity of these sub-districts to drought. The sub-districts with comparatively high adaptive capacity to drought include Sengaon, Basmath, Lohara, Parli, Parbhani, Ashti, Latur, Osmanabad, Washi, Bhum and Tuljapur because of their comparatively better irrigation support, lesser share of geographical land under landholdings occupied by marginal and small farmer, level of literacy and medical facilities (Directorate of census operations Maharashtra 2011). It is significant to observe that among them Parli and Tuljapur lies under the class of low drought vulnerability, Sengaon, Basmath, Lohara, Parbhani, Latur, Washi and Bhum have moderate drought vulnerability while Ashti and Osmanabad have high drought vulnerability because of the higher exposure and sensitivity of these two sub-districts. Ardhapur (32.29\%) has the highest percentage of irrigated crop area in the region while Tuljapur (30.01\%) has the lowest percentage of area under landholdings less than 2 hectares. These are among the important factors which make Ardhapur and Tuljapur to fall under the class of low drought vulnerability (Directorate of census operations Maharashtra 2011).

The basic methodology of drought vulnerability could be applied to similar semi-arid geographical regions. However, the selection of appropriate region-specific drought vulnerability indicators and assignation of weights are some critical issues that leaves the scope to improve the methodology for future research. Nevertheless, this study could positively be a step towards developing an integrated geospatial approach for the assessment of drought vulnerability at sub-district level in a chronically drought affected Marathwada region.

\section{Conclusion}

By taking into consideration the worldwide initiatives toward drought risk reduction, this study realizes greater significance to existing drought risk reduction strategies. In this study, an integrated approach has been adopted for addressing the multidimensional nature of drought vulnerability by integrating the biophysical and socioeconomic indicators. The Marathwada region receives erratic rainfall and frequently drought affected area covers fairly large geographical extent of the region. The drought vulnerability indicators and the drought vulnerability composite index are computed at sub-district level, thus enhancing the quality of research. The composite index has quantitatively assessed the drought vulnerability and shows the spatial relative differences at the subdistrict level. The sub-districts of Marathwada region, i.e., Shirur-Anantpal, Deoni, Shirur Kasar, Dharur, Biloli, Paranda, Mukhed, Khuldabad, Patoda, Hadgaon, Palam, Badnapur and Kaij emerged as the very highly vulnerable to drought, representing $14.43 \%$ of geographical area and $10.96 \%$ of population of Marathwada. The sub-districts lying under the high drought vulnerability category represented $39.15 \%$ of geographical area and $34.69 \%$ of population. While the sub-districts lying under the moderate drought vulnerability category represented $41.51 \%$ of geographical area and $50.15 \%$ of population of the region. The sub-districts like Soegaon, Tuljapur, Ardhapur and Parli lies at the bottom of the category representing $4.90 \%$ of geographical area and $4.21 \%$ of population.

However, remedial analysis of vulnerable subdistricts needs to be done for improving the existing action plans. Strategies need to be evolved for reducing the impacts of drought on local population by increasing the adaptive capacity. The water conservation practices like the construction of soak pits, farm ponds, Nala (drainage) widening, and contour trenches results into improved groundwater recharge. The lack of perennial water bodies in the study area increases the dependency on groundwater. It makes groundwater resources very dynamic that requires constant monitoring. With the introduction of possible modifications in cropping pattern and crop calendars according to the annual meteorological predictions could be some concrete measures in reducing the drought vulnerability and improving the agricultural performance of the Marathwada region. The adoption of sub-district specific action plans will not only reduce the drought vulnerability but also contribute to the holistic development of water resources in the region.

\section{Acknowledgement}

The present research work is supported by the financial grant from University Grant Commission (UGC), Government of India through Senior Research Fellowship to Sagar Khetwani. The authors are thankful to the agencies of Government of Maharashtra like Groundwater Surveys and Development Agency and Department of Agriculture for making the data timely available. The present research paper is taken from the doctoral research work of Sagar Khetwani, submitted to the University of Delhi. 


\section{References}

Action Aid (2016) Drought 2015-16 lessons from desolation: A citizen's report on impact of drought and learnings for future. New Delhi.

Basu R, Singh, CK, Eslamian, S (2017) Cause and occurrence of Drought. In: Eslamian S, Eslamian F (eds) Handbook of drought and water scarcity: environmental impacts and analysis of drought and water. CRS Press, Boca Raton (FL), pp. 137-148.

Centre for Research on the Epidemiology of Disasters (2015) The human cost of natural disasters: A global perspective. CRED, Brussels.

Dalezios NR, Alfonso AMT, Eslamian S (2017) Drought assessment and risk analysis. In: Eslamian S, Eslamian F (eds) Handbook of drought and water scarcity: environmental impacts and analysis of drought and water. CRS Press, Boca Raton (FL), pp. 323-344.

Dandekar P, Thakkar H (2013) How is 2012-13 Maharashtra drought worse than the one in 1972?. 30 March 2013. SANDRP Blog. Available from: <https://sandrp.in/2013/03/30/howis-2012-13-maharashtra-drought-worse-than-the-one-in-1972> [14.08.2017]

Deulgaonkar A (2015) This is the worst drought in the history of Marathwada. DNA 1 October. Available from: <https://www.dnaindia.com/analysis/interview-this-is-theworst-drought-in-the-history-of-marathwada-atul-deulgaonkar2130577> [18.03.2017]

Directorate of census operations Maharashtra (2011) District Census HandBook - Maharashtra. Available from: <https://censusindia.gov.in/2011census/dchb/Maharashtra.html> [05.10.2018]

Fakhruddin BSHM, Eslamian S (2017) Analysis of drought factors affecting the economy. In: Eslamian S, Eslamian F (eds) Handbook of drought and water scarcity: environmental impacts and analysis of drought and water. CRS Press, Boca Raton (FL) pp. 643-655.

Groundwater Surveys and Development Agency (2017) Aurangabad Region. Available from: <https://gsda.maharashtra.gov.in/english/index.php/Regions_Information_InDetailed/in$\operatorname{dex} / 6>$ [07.03.2017]

Haque MM, Ahmed A, Rahman A, Eslamian S (2017) Drought losses to local economy. In: Eslamian S, Eslamian F (eds) Handbook of drought and water scarcity: environmental impacts and analysis of drought and water. CRS Press, Boca Raton (FL), pp. 627-642.

Hayes M, Svoboda M, Comte DL, Redmond KT, Pasteris P (2005) Drought monitoring: New tools for the 21st Century. In: Wilhite DA (eds) Drought and water crises: Science, technology, and management issues. CRS Press, Boca Raton (FL), pp. $53-69$.

Hohenthal J, Minoia P (2017) Social aspects of water scarcity and drought. In: Eslamian S, Eslamian F (eds) Handbook of drought and water scarcity: environmental impacts and analysis of drought and water. CRS Press, Boca Raton (FL), pp. 607-626.

Kale S, Gond JK (2016) Drought in Marathwada: Water scarcity worsening situation in Marathwada. International Journal of Innovative Research in Science, Engineering and Technology 5(5): 8376-8384.
Kar SK, Thomas T, Singh RM, Patel L (2018) Integrated assessment of drought vulnerability using indicators for Dhasan basin in Bundelkhand region, Madhya Pradesh, India. Current Science 115(2): 338-346.

Karamouz M, Zeynolabedin A, Olyaei MA (2015) Mapping regional drought vulnerability: A case study. International Conference on Sensors \& Models in Remote Sensing \& Photogrammetry, 23-25 Nov 2015, Kish Island, Iran. The International Archives of the Photogrammetry, Remote Sensing and Spatial Information Sciences 41(5): 369-377.

Kayam Y, Beyazgul M (2017) New approaches for effective drought risk assessment. In: Eslamian S, Eslamian F (eds) Handbook of drought and water scarcity: environmental impacts and analysis of drought and water. CRS Press, Boca Raton (FL), pp. 345-360

Maharashtra Status of Environment and Related Issues (ENVISMAH) (2007) Environmental status report of Aurangabad Region.

Murthy CS, Laxman B, Sesha Sai MVR (2015a) Geospatial analysis of agricultural drought vulnerability using a composite index based on exposure, sensitivity and adaptive capacity. International Journal of Disaster Risk Reduction 12: 163-171.

Murthy CS, Yadav M, Ahamed JM, Laxman B, Prawasi R, Sesha Sai MVR, Hooda RS (2015b) A study on agricultural drought vulnerability at disaggregated level in a highly irrigated and intensely cropped state of India. Environmental Monitoring and Assessment 187: 140

Peters JA, Elizabeth A, Walter S, Lei J, Andres V, Michael H, Mark DS (2002) Drought monitoring with NDVI-based standardized vegetation index. Photogrammetric Engineering and Remote Sensing 68: 71-75.

Planning Department Government of Maharashtra (PDGOM) (2013) Report of the High Level Committee on Balanced Regional Development Issues in Maharashtra. Government of Maharashtra

Polsky C, Cash DW (2005) Drought, climate change, and vulnerability: The role of science and technology in a multi-scale, MultiStressor World. In: Wilhite DA (eds) Drought and water crises: Science, technology, and management issues. CRS Press, Boca Raton (FL), pp. 215-245.

Rama Rao CA, Raju BMK, Subba Rao AVM, Rao KV, Rao VUM, Ramachandran K, Venkateswarlu B, Sikka AK, Srinivasa Rao M, Maheswari M, Srinivasa Rao CH (2016) A district level assessment of vulnerability of Indian agriculture to climate change. Current Science 110(10): 1939-1946.

Ravindranath NH, Rao S, Sharma N, Nair M, Gopalakrishnan R, Rao AS, Malaviya S, Tiwari R, Sagadevan A, Munsi M, Krishna N, Bala G (2011) Climate change vulnerability profiles for North East India. Current Science 101(3): 384-394.

Squires VR (2017) Desertification and drought. In: Eslamian S, Eslamian F (eds) Handbook of drought and water scarcity: environmental impacts and analysis of drought and water. CRS Press, Boca Raton (FL), pp. 13-26.

Swain M, Swain M (2011) Vulnerability to agricultural drought in Western Orissa: A case study of representative blocks. Agricultural Economics Research Review 24: 47-56.

Swami D, Dave P, Parthasarathy D (2018) Agricultural susceptibility to monsoon variability: A district level analysis of Maharashtra, India. Science of the Total Environment 619-620: 559-577.

Thomas T, Jaiswal RK, Galkate R, Nayak PC, Ghosh NC (2016) Drought indicators-based integrated assessment of drought vulnerability: A case study of Bundelkhand droughts in central India. Natural Hazards 81: 1627-1652. 


\section{S sciendo}

Vedeld T, Aandahl G, Barkved L, Kelkar U, Bruin KDE, Lanjekar P (2014) Drought in Jalna: Community-based adaptation to extreme climate events in Maharashtra, The Energy and Resources Institute (TERI), New Delhi.
Wilhite DA, Hayes MJ, Knutson CL (2005) Drought Preparedness Planning: Building Institutional Capacity. In: Wilhite DA (eds) Drought and Water Crises: Science, Technology, and Management Issues. CRS Press, Boca Raton (FL), pp. 93-135. 